\title{
A Study on Sthalavrikshas in Temples of Madurai District, Tamil Nadu
}

\author{
Vinoth Kumar $\mathbf{A}^{1 *}$ and Aruna $\mathbf{R}^{2}$ \\ ${ }^{1}$ Department of Botany, Research Scholar, PG and Research Virudhunagar, India \\ ${ }^{2}$ Department of Botany, Assistant Professor, PG and Research, Madurai, India
}

Submission: June 06, 2018; Published: July 17, 2018

*Corresponding author: Vinoth kumar, Department of Botany, Research Scholar, PG and Research Virudhunagar, India,

Email: a.vinothbot@gmail.com

Abstract

India delivers rich biodiversity and it is not just the world's twelve mega diverse countries, but also one of the eight major centers of origin and diversification of domesticated taxa. These taxa are conserved and have been considered sacred because of their cultural, religious and economic importance. In Tamil Nadu, some sacred trees are in the status of extinct, endangered, threatened, and vulnerable and vary rare habit. The sacred trees are very good examples of ex situ conservation, where a single plant is conserved and worshipped. A study of Sthalavrikshas is also known as sacred trees (or) temple trees was conducted in the temples of the Madurai district during 2016-2017. The study revealed the presence of Sthalavrikshas in 65 temples out of 100 temples studied. Totally 31 species of Sthalavriksha recorded in these 65 temples.

Keywords: Biodiversity; Conservation; Sthalavrikshas

\section{Introduction}

Sacred groves and sthalavriksha (temple tree) have been acting as a major role in the conservation of plants and animals. In the location are certain ethnic groups and residential district in India, which have been worshiping forests, trees and certain animals since time immemorial. Occurrence of sacred groves at several spaces in India, clearly defines the community's attachment to nature. Sacred plants play a really significant role in ecology. Due to their ecological value and effective properties, sacred plants continue to be employed in the religious and social festivals of the Hindus. The five most sacred leaves of pipal, Cluster fig, white fig, banyan and mango are ubiquitously employed in making prayers and oblations. On auspicious occasions, mango leaves are attached to train and strung up on doors as a welcome banner, and leaves of purasu and banyan make workable plates and bowls during community feasts. Leaves of some other trees are also customarily offered to deities e.g., Vilvam (Bengal quince) to Lord Siva, of banana and Arjuna to Lord Ganesha, and of kontrai (Cassia fistula) to all the gods and goddesses. The red flowers of the Indian coral tree are used in the worship of Lord Vishnu and Lord Siva; of Alari (Nerium indicum) in the worship of Lord Siva and the Sun-god; of ketaki (Yucca gloriosa) in the worship of Lakshmi, and of pala or breadfruit (Artocarpus integrifolia) in the worship of Lord Vishnu. The purpose of some flowers is prohibited in worship rites like vaagai (sirisa or parrot tree/Albizia lebbeck) in the worship of Lord Ganesha and vengai (Pterocarpus marsupium) in the worship of Lord Siva. The wood of the sacred trees like vilvam, banyan, vanni, purasu and pipal is never employed as fuel, as it is believed to invite the anger of gods. But it is employed in other ways, in sacrificial rites and ceremonies. Sudhakar [1]. Sthalavriksha worship in temples is a popular exercise. Most of these temples have their own Sthalavrikshas (temple trees) and Nanthavanam (flower garden). Sacred plants provide food, shelter and nesting substratum for several species of birds and squirrels. All souls of certain species are completely protected. Sthalavriksha is a natural tree found in the temple site before construction of the temple and most temple myths (Sthalapuranas) and temple histories (Sthalavaralaru) refer to a prime deity that was first unearthed or found under the tree Gunasekaran \& Balasubramanian [2]. Every temple has one plant or tree as sthalavriksham. Sthalavriksha means the tree of the locality (sthal-place; vriksha-tree). In Tamilnadu state, about sacred trees are in the status of extinct, endangered, threatened, and vulnerable and vary rare habit. Such trees are both ethno botanically or culturally important and ecological representative of the area.

Sthalavriksha or temple tree is a single plant worshipped as equal as the prime deity in the temples. In both Hinduism and Buddhism, temple tree worship holds a bigger significance. The plant, primarily worshipped are Peepal (Ficus religiosa), Neem (Azardirachta indica), Bael (Aegle marmelos), Sandalwood (Santlum album), etc. There are temples which have more than one Sthalavriksham simultaneously, whereas some temples like a Sri Kallalagar temple (Prosopis cineraria (L.) Druce and 
(Pterocarpus santalinus L.f.) to have different Sthalavriksham is different yugas. On that point are also examples of more than temple having the same trees as sthalavriksham (eg.) Aegle marmelos (L.) Corr.serr. and Azardirachta indica Adr. Juss. etc. Some of the important temple festivals are associated with the sthalavriksham of the temples concerned mavadi sevai of kanci Ekambareswara temple and makizhadi sevai of tiruvottiyur temple are two such festivals. Sthalavriksha mostly occurs in tree habit, in main or big temples of Tamilnadu. In some temples, it occurs in herb, shrub, grass or climber forms. Sacred trees are therefore handled as any other sacred space, and it is thus not surprising that many of the customs and ceremonies mentioned in sacred places, in general, are also observed at the sites of sacred trees. This habit shows characteristically the importance of medicinal plants in Indian System of Medicine. Medicinal parts of the Sacred Trees (Sthalavrikshas) are practiced in different forms. It is presented in the form of paste, juice, dried powder and made into tablets and juices mixed with sugar and honey to cure various diseases Amirthalingam [3].

\section{Materials and Methods}

\section{Study Area}

Historical Background: Madurai is one of the major districts of Tamilnadu State. Madurai is located along the bank of the river Vaigai. It is an ancient urban center known for its age old legacy and agile of contemporary modern lifestyle-a singular spot for worship and the Modern-day of living. Madurai is also visited by different names like "City of Jasmine" (Malligai maanagar), "Temple City" (Koil maanagar), "City that never sleeps" (Thoonga Nagaram) and "City of four junctions" (Naanmada koodal).

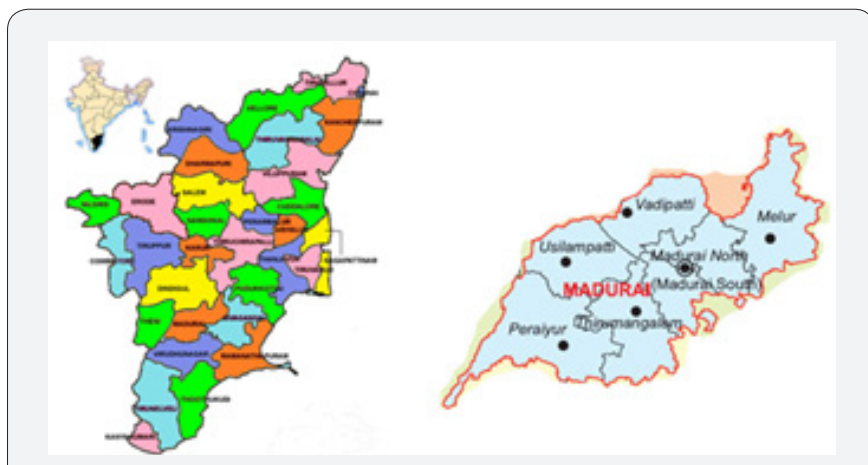

Figure 1.

Location \& Geographical Area: The Madurai district lies between $9^{\circ} 56^{\prime} 20.7348^{\prime \prime} \mathrm{N}$ and $78^{\circ} 7^{\prime} 18.1884^{\prime \prime}$ E. It takes in an area of $3741.73 \mathrm{Sq} . \mathrm{Km}$ and is bordered on the west by Theni district, on the north by Dindigul district, on the east by Sivagangai district and along the south by Virudhunagar district. The district is empowered with a semi arid tropical climate with normal rainfall of $827.1 \mathrm{~mm}$ as against $923.1 \mathrm{~mm}$ for the state. The present study was extended out in Madurai district, Tamilnadu. 130 temples were enumerated, data gathered from the local people. Flowering twigs of trees set up within the temple premises were collected and identified taxonomically using the Floras. The tree species grown as Sthalavriksha in 65 temples in Madurai district were enumerated. The survey documented several interesting facets of tree worship. The local people, including Temple handoff, Priests, Temple Defendable and Worshipers was interacted with temple area of Madurai district that have indigenous knowledge about sacred plants of their locality and information's were collected by group discussions and interviews with them in their local language (Tamil). Binomials of the plants with family, their local names, parts used and Medicinal uses were recorded (Figure 1).

Interview and Ethno Medicinal Data Collection: The ethno medicinal information was collected by interacting with the priest and people living around the temples through interview as a recorded data.

Collection of Plant: The floral parts and twigs were collected from the Sthalavriksha for Binomial name identification. Generally, the plant specimens were collected with flower and fruit. In case, if there are no flowers and fruit conditions, the plant twig with few leaves was collected for proper identification.

\section{Result}

Sthalavriksha worship in temples is an ancient religious practice in India. This study is the first attempt to survey the Sthalavrikshas of 100 temples in Madurai district. Tamilnadu, India. Of the surveyed 100 temples, there were only 68 temples in which Sthalavriksha were present. The temples found among them 12 were Lord Shiva temples, 28 were Lord Amman temples, 7 were Goddess Sakthi temples, and 7 were Lord Murugan temples, 3 were Vinayaga temples, 11 various deity temples. A total of 31 plant species belonging 20 families was recorded in the study. Most of these plants belong to Dicotyledons of angiosperms and one species belong to Monocotyledons (Borassus flabellifer L.). 30 Sthalavriksha plants were trees while one was a shrub (Tabernaemontana divaricata R.Br.ex Roem \& Schult.). All the Sthalavrikshas documented in the study are given in Table 1 In Madurai district; the ancient temples were recorded for this study. The temples include Meenakshi Amman temple, Kallalagar temple, Thiruvaapudaiyar temple, Inmailum Nanmai Taruvar Temple, Puttu Sokanathar Temple etc. A total of 31 Sthalavriksha species belonging to 20 families were recorded, and Dominant families were Moraceae and Fabaceae with 4 species each, Moraceae, represented by 4 species (Ficus benghalensis L. Ficus microcarpa L.f. Ficus religiosa L. Ficus tintoria G.Forst). Fabaceae represented by 4 species (Prosopsis cineraria (L.) Druce, Pterocarpus santalinus L.f. Acacia leucophloea Wild. and Prosopsis cineraria (L.) Druce) and the other dominated families were Anacardiaceae and Mimosaceae. Each family is represented by 2 species, Mimosaceae (Albizia amara (Roxb.) Acacia nilotica (L.) Willd. ex Del.) and Anacardiaceae, includes 2 species (Lannea coromandelica (Houtt.) Merr and Mangifera indica L.) Among these Rutaceae was the dominant family represented by 16 temples followed by Moraceae represented by 6 temples and followed by Meliaceae and Rubiaceae represented 
by 4 temples each. The frequently occurring species was Aegle marmelos (L.) Correa recorded in 17 temples followed by Ficus benghalensis L. Druce in 6 temples and Azardirachta indica Adr. Juss and Neolamarckia cadamba (Roxb.) Bosser was recorded in 4 temples each. All the 31 species were reported to have medicinal properties. Tholkappiyavathi et al., (2013) reported that 16 temples have Sthalavrikshas while 20 such element exists in remaining temples. 9 species of Sthalavrikshas have been recorded in these 16 temples. Prabakaran et al. [4] surveyed the sthalavriksha of 106 temples in Salem, Namakkal, Karur district. They record sthalavriksha were found in 81 temples and a total 18 plant species belong to 18 genera and 14 families.Among this Caesalpiniaceae was the dominant family represented by 3 species followed by Rutaceae and Moraceae represented by 2 species each (Figure 2).

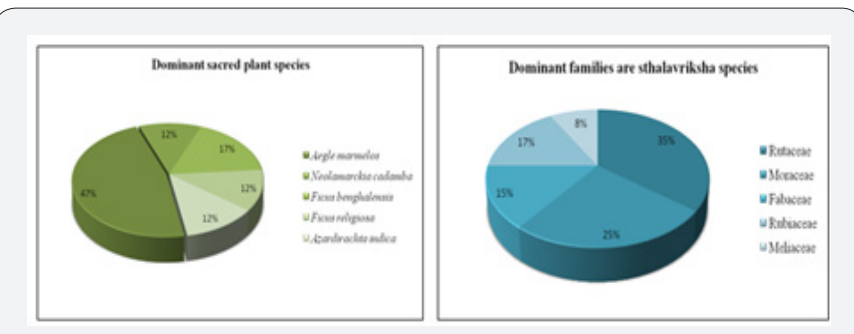

Figure 2.

\section{Economically Important on Species}

Most of the plants put down from sacred plants (Sthalavriksha) of Madurai district are economically significant. The medicinal plants comprise about 31 species, 29 species having timber value and 19 species were regarded for minor forest produce. Many multipurpose species have also been reported from the groves. Of these, 23 species are used as timber and medicine, 34 species as medicine and minor forest produce, 18 species as minor forest products and timber, and 10 species as timber, medicine and minor forest produce. Sukumaran et al. [5] reported 329 species belonging to 251 genera of 100 families and economically important plants such as medicinal value (194 sp.), timber value (34sp.) and minor forest product (19sp.) (Figure 3).

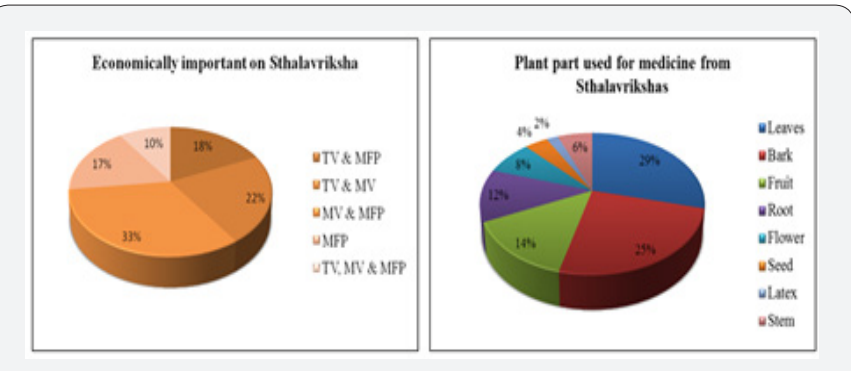

Figure 3.

\section{Quantitative Analyses of Medicinal Use}

The village people have used the Sthalavriksha plants for many ills. It may be noted here that most of the sacred trees usually have great medicinal value. Traditional medicine continues to act as an important role in health maintenance. Medicinal parts of the Sacred Trees (Sthalavrikshas) are practiced in dissimilar kinds. It is presented in the form of a paste, juice, dried powder and juices mixed with sugar and honey to cure several diseases. The similar documented was made for 31 plants belong to 20 families are identified as traditional medical used species (Table 2). Gastrointestinal problems like digestive problems, diarrhea, dysentery, stomach ache and constipation were treated using specific herbal prescriptions by the local peoples same reported. Respiratory problem like cough, cold, and asthma also used medicinal plant. The plant parts, mostly reported in this regard were Leaves (29\%), Bark (25\%), Fruit (14), Root (12\%), Flower (8\%), Stem (6\%), Seed (4\%) and Latex (2\%). Gunasekaran et al. [6] Ethnomedicinal uses of 91 Sthalavrikshas (temple trees) in Tamil Nadu, southern India, posses medicinal uses and cured various diseases like Toothache, Dysentery, Stomach ache, Diar $\neg$ rhea, etc.

\section{Medicinal Preparations}

The medicinal preparations followed by the Sthalavrikshas of Madurai district to cure a disease were based on many kinds of preparations which are as follows.

a) Decoction: A decoction was obtained by boiling the plant in water until the volume of liquid was reduced to more than $1 / 2$ or $3 / 4$ of the original amount of liquid.

b) Extract: The plant material was ground with some amount of water as per the need and filtered. The filtrate was used as an extract.

c) Juice: The juice was obtained by grinding the plant material and this preparation was administered wholly (This juiciest material used for filtered or non-filtered)

d) Latex: Latex was obtained by detaching the leaf or young stem at normal region of the plants and used.

e) Paste: The paste was prepared by grinding fresh, dried material with water.

f) Powder: The powder was prepared by grinding dried material.

g) Raw: The plant material is also used in raw form, was used immediately after harvesting.

It was also likewise mentioned that the sthalavrikshas in Madurai district in Tamilnadu used the medicinal preparation mostly in the form of Paste (19\%), followed by decoction (20\%), juice (20\%), extract (15\%), Powder (9\%), Raw and Latex (17\%). Some of the sacred plants cure to various diseases, taken from various forms, such as Aegle marmelos species bark decoction is used to treat intermittent fever. Bark powder used for skin diseases. Leaf act as a blood purifier. Cassia fistula species taken from various forms, Leaf (paste) flower (juice) and root (extract) cured of some diseases such as skin diseases, snakebite, fever and cold. Gunasekaran et al. [6]- Ethno medicinal uses of 91 Sthalavrikshas (temple trees) in Tamil Nadu, southern India, 
they reported medicinal uses and taken from various formations such as juice, decoction, powder, paste, used to cure for various diseases and ailments like Diarrhea, fever, cough, cold, etc.

From the present investigation, it was noted that the Sthalavriksha plants on Madurai district of the study area used to herbal preparation made from the medicinal plants mostly used for the treatment of diarrhea (5 species: Aegle marmelos, Mangifera indica, Acacia nilotica, Morinda tinctoria, Tamarindus indica), dysentery (5 species: Acacia nilotica, Acacia leucophloea, Syzygium cumini, Tabernaemontana divaricata, Morinda tinctoria), fever (5 species: Acacia leucophloea, Aegle marmelos, Mimusops elengi, Morinda tinctoria, Neolamarckia cadamba), cough (5 species: Ailanthus excels, Acacia leucophloea, Lepisanthes tetraphylla, Prosopis cineraria, Millingtonia hortensis), skin diseases (9 species: Aegle marmelos, Azardirachta indica,
Alangium salviifolium, Cassia fistula, Ficus religiosa, Millingtonia hortensis, Pongamia pinnata, Pterocarpus santalinus, Borassus flabellifer). Gunasekaran et al. [6] - Ethnomedicinal uses of 91 Sthalavrikshas (temple trees) in Tamil Nadu, southern India, they reported medicinal plants, mostly cured of fever (23 species), dysentery (13 species), asthma (10 species), rheumatism (10 species) and diarrhea (8 species). Nandkishor et al. [7] reported that the Some Sacred Trees and their Medicinal Uses from Amravati District (Maharashtra), used the medicinal plants, mostly for the treatment of fever (12 species), followed by dysentery (8 species) and diarrhea (3 species) [8-10].

\section{Conservation Status of the Plants}

The plant species Pterocarpus santalinus comes under the endangered category, all other species are of least concerned status (Table 1).

Table 1: List of Sthalavriksha Species.

\begin{tabular}{|c|c|c|c|c|c|c|c|}
\hline S.No & Botanical Names & Family & Habit & Local name & Temple Name & IUCN Status & $\begin{array}{c}\text { No of } \\
\text { Individuals }\end{array}$ \\
\hline 1 & Acacia leucophloea Wild. & Mimosaceae & Tree & Velamaram & Mathichiya karupu & Least Concern & 2 \\
\hline 2 & Acacia nilotica (L.) Willd. ex Del. & Mimosaceae & Tree & Palkrucelai & Ellai karupha & Least Concern & 1 \\
\hline 3 & Aegle marmelos (L.) Corr.serr. & Rutaceae & Tree & Vilvam & Agnieaswer & Least Concern & 16 \\
\hline 4 & Ailanthus excelsa Roxb. & Simaroubaceae & Tree & Peru & $\begin{array}{c}\text { Periya } \\
\text { kathavarayan }\end{array}$ & Least Concern & 1 \\
\hline 5 & $\begin{array}{c}\text { Alangium salviifolium (L.f.) } \\
\text { Wangerin }\end{array}$ & Cornaceae & Tree & Alangi & Munisamy & Least Concern & 2 \\
\hline 6 & Albizia amara (Roxb.) & Mimosaceae & Tree & Usilaimaram & Periya ayyan & Least Concern & 1 \\
\hline 7 & Azardirachta indica Adr. Juss. & Meliaceae & Tree & Vembu & Kaaliamman & Least Concern & 4 \\
\hline 8 & Borassus flabellifer L. & Arecaceae & Tree & Panai & Muniyandi & Least Concern & 1 \\
\hline 9 & Cassia fistula L. & Fabaceae & Tree & Sarakontrai & Thiruvappudaiyar & Least Concern & 1 \\
\hline 10 & $\begin{array}{l}\text { Crateva adansonii DC.ssp.odora } \\
\text { (Buch.Ham.) M.Jacobs }\end{array}$ & Capparaceae & Tree & Mavilingam & $\begin{array}{c}\text { Kadasari } \\
\text { nallakurumpa }\end{array}$ & Least Concern & 1 \\
\hline 11 & Ficus benghalensis L. & Moraceae & Tree & Alamaram & Kanni kamachi & Least Concern & 6 \\
\hline 12 & Ficus microcarpa L.f. & Moraceae & Tree & Ithimaram & Pandi aandi & Least Concern & 1 \\
\hline 13 & Ficus religiosa L. & Moraceae & Tree & Arasu & Madhana gopalan & Least Concern & 4 \\
\hline 14 & Ficus tintoria G. Forst & Moraceae & Tree & Kallathi & $\begin{array}{l}\text { Supiraminiya } \\
\text { swami }\end{array}$ & Least Concern & 1 \\
\hline 15 & $\begin{array}{c}\text { Lannea coromandelica (Houtt.) } \\
\text { Merr. }\end{array}$ & Anacardiaceae & Tree & Uthiyamaram & $\begin{array}{l}\text { Manathiraiyan } \\
\text { amman }\end{array}$ & Least Concern & 2 \\
\hline 16 & $\begin{array}{c}\text { Lepisanthes tetraphylla (Vahl) } \\
\text { Radlk }\end{array}$ & Sapindaceae & Tree & Kookamathi & Cinna puli ayyanar & Least Concern & 2 \\
\hline 17 & Mangifera indica L. & Anacardiaceae & Tree & Maа & Mottu kaiyan & Least Concern & 1 \\
\hline 18 & Millingtonia hortensis L.f. & Bignoniaceae & Tree & Kattumalli & $\begin{array}{l}\text { Ellamal \& } \\
\text { pappamal }\end{array}$ & Least Concern & 1 \\
\hline 19 & Mimusops elengi L. & Sapotaceae & Tree & Magizham & Thirupaapudaiyar & Least Concern & 1 \\
\hline 20 & Morinda tinctoria Roxb. & Rubiaceae & Tree & Manjanathi & Ellai amman & Least Concern & 4 \\
\hline 21 & Musa paradisiaca L. & Musaceae & Tree & Vazhai & $\begin{array}{c}\text { Koodalagar } \\
\text { perumal }\end{array}$ & Least Concern & 1 \\
\hline 22 & $\begin{array}{l}\text { Naringi crenulata (Roxb.) } \\
\text { Nicolson }\end{array}$ & Rutaceae & Tree & $\begin{array}{l}\text { Thasathala } \\
\text { vilvam }\end{array}$ & $\begin{array}{l}\text { Imailum } \\
\text { nanmai tharum } \\
\text { thiruvapudayar }\end{array}$ & Least Concern & 1 \\
\hline 23 & $\begin{array}{c}\text { Neolamarckia cadamba (Roxb.) } \\
\text { Bosser }\end{array}$ & Rubiaceae & Tree & Kadambam & $\begin{array}{l}\text { Sri meenachi } \\
\text { sokkanathar }\end{array}$ & Least Concern & 4 \\
\hline
\end{tabular}




\section{International Journal of Environmental Sciences \& Natural Resources}

\begin{tabular}{|c|c|c|c|c|c|c|c|}
\hline 24 & Pongamia pinnata (L.) Pierrc & Fabaceae & Tree & Punnai & Naagar & Least Concern & 1 \\
\hline 25 & Prosopis cineraria (L.) Druce & Fabaceae & Tree & Vanni & Kallalagar & Least Concern & 1 \\
\hline 26 & Pterocarpus santalinus L.f. & Fabaceae & Tree & Santhanamaram & Kallalagar & Endangered & 1 \\
\hline 27 & Syzygium cumini (L.) Skeels & Myrtaceae & Tree & Naval & Pazhamudhir solai & Least Concern & 2 \\
\hline 28 & $\begin{array}{c}\text { Tabernaemontana divaricata } \\
\text { R.Br. ex Roem. \& Schult. }\end{array}$ & Apocynaceae & Shrub & Nanthiyavattai & $\begin{array}{c}\text { Seiya mutthaiya } \\
\text { ayyanar }\end{array}$ & Least Concern & 1 \\
\hline 29 & Tamarindus indica L. & Caesalpinaceae & Tree & Puli & Ayyanar & Least Concern & 1 \\
\hline 30 & $\begin{array}{c}\text { Terminalia arjuna (Roxb.ex DC.) } \\
\text { Wight \& Arn. }\end{array}$ & Combretaceae & Tree & Maruthu & $\begin{array}{c}\text { Marutha kaali } \\
\text { amman }\end{array}$ & Least Concern & 1 \\
\hline 31 & $\begin{array}{c}\text { Thespesia populnea (L.) Sol.ex } \\
\text { Corr. Serr. }\end{array}$ & Malvaceae & Tree & Puvarasu & $\begin{array}{c}\text { Veyil ugantha } \\
\text { amman }\end{array}$ & Least Concern & 1 \\
\hline
\end{tabular}

Table 2: Ethinomedicinal uses of sacred plants.

\begin{tabular}{|c|c|c|c|}
\hline S.No & Botanical Names & Plant part & Medicinal uses \\
\hline 1 & Acacia leucophloea Wild. & Leaf, bark, root & Cough, throat infection, dysentery \\
\hline 2 & Acacia nilotica (L.) Willd. ex Del. & Leaf & Diarrhea, dysentery \\
\hline 3 & Aegle marmelos (L.) Corr.serr. & Whole plant & Fever, diarrhea, skin disease \\
\hline 4 & Ailanthus excelsa Roxb. & Bark & Cough and cold \\
\hline 5 & Alangium salviifolium (L.f.) Wangerin & Fruit & Eye disease \\
\hline 6 & Albizia amara (Roxb.) & Gum & Ulcer \\
\hline 7 & Azardirachta indica Adr. Juss. & Whole plant & Skin infection, malaria \\
\hline 8 & Borassus flabellifer $\mathrm{L}$. & Fruit & Skin disease \\
\hline 9 & Cassia fistula L. & Leaf, flower, root & Skin disease, snake bite \\
\hline 10 & Crateva adansonii DC.ssp.odora (Buch.Ham.) M.Jacobs & Bark, leaf & Stomach troubles, jaundice \\
\hline 11 & Ficus benghalensis $\mathrm{L}$. & Whole plant & Toothache, female sterility \\
\hline 12 & Ficus microcarpa L.f. & Leaf, bark & Headache, liver diseases, stomach pain \\
\hline 13 & Ficus religiosa $\mathrm{L}$. & Leaf, bark & Jaundice, skin diseases, ulcer \\
\hline 14 & Ficus tintoria G. Forst & Leaf & Broken bones \\
\hline 15 & Lannea coromandelica (Houtt.) Merr. & Bark & Stomach pain \\
\hline 16 & Lepisanthes tetraphylla (Vahl) Radlk & Leaf, stem & Cough \\
\hline 17 & Mangifera indica $\mathrm{L}$. & Seed & Diarrhea \\
\hline 18 & Millingtonia hortensis L.f. & Root, leaf & Skin disease, cough, lung disorder \\
\hline 19 & Mimusops elengi $\mathrm{L}$. & Bark, flower, fruit & Headache, urinary blander, fever \\
\hline 20 & Morinda tinctoria Roxb. & Leaf, fruit & Diarrhea, digestion problem, wound, fever \\
\hline 21 & Musa paradisiaca $\mathrm{L}$. & Whole plant & Kidney and urinary bladder \\
\hline 22 & Naringi crenulata (Roxb.) Nicolson & Leaf & Vomiting \\
\hline 23 & Neolamarckia cadamba (Roxb.) Bosser & Bark, leaf & Fever, mouth gargle, stomach pain \\
\hline 24 & Pongamia pinnata (L.) Pierrc & Seed & Skin problems \\
\hline 25 & Prosopis cineraria (L.) Druce & Bark & Rheumatism, cold \\
\hline 26 & Pterocarpus santalinus L.f. & Wood & Inflammatory disease, skin disease \\
\hline 27 & Syzygium cumini (L.) Skeels & Leaf, fruit & Abdominal pain, dysentery, sore throat \\
\hline 28 & Tabernaemontana divaricata R.Br. ex Roem. \& Schult. & Root, latex & Dysentery, healing wounds, eye diseases \\
\hline 29 & Tamarindus indica $\mathrm{L}$. & Flower, fruit & Diarrhea, blood purifier \\
\hline 30 & Terminalia arjuna (Roxb.ex DC.)Wight \& Arn. & Bark & Urinary disorders \\
\hline 31 & Thespesia populnea (L.) Sol.ex Corr. Serr. & Bark, leaf & Join pains, reeumatism \\
\hline
\end{tabular}

\section{The Necessity of Security}

Sthalavrikshas worshipped in plants are a means of conservation of plants. Plants in the temple gardens are cultivated and maintained and this is also a means of conservation of plants. The role of people in the conservation of plant has been an age old practice since historic period. It was concluded that the Sthalavriksha worship is an age old practice; myths, beliefs and this practice play a major role in the conservation of plants. 
Thus, the above results and discussion proved the relation of the human and the nature towards plant conservation. The traditional worshipping has protected many plants which have tremendous medicinal value and made them as sacred, so that with the fear of deity nobody eradicates it. So we have to protect these sacred plants for us and our next generation for better survival. On the basis of this study, we have to follow our ancestor's belief in humanity and nature sustainability.

\section{Conclusion}

Madurai district, unitary of the ancient districts of Tamil Nadu famous for its religious culture, was studying for the sthalavriksha plants. It was noted that a total of 31 plant species was recorded. The recorded plant species belong to 20 families. Among that family of Moraceae and Fabaceae dominated together with 4 species followed by Rutaceae, Rubiaceae, Anacardiaceae and Mimosaceae family consequently represented with 2 plant species. Medicines are obtained from the Sthalavrikshas and are used in different forms. Sthalavrikshas are valued for their botanical, medicinal, environmental, religious and mythical importance. The sthalavrikshas of Tamilnadu constitute a lot of genetic resources for the conservation of species diversity. Propagation of sthalavrikshas in temples contributes to the conservation of our floral diversity. Some trees are significant for their economic use of shipbuilding or in the timber industry, some for providing homes for various animals, birds, and others for their medicinal value. In the present study, it is concluded that the religious activities are having a close relationship with plants boost up the mental health of local people of Madurai district and many of the sacred plants found in the household and temples were used for various religious cultural activities as well as for health care. These sacred plants are worshiped by the local people for getting the blessing of health and wealth by positive powers of nature. Hence the religious ceremonies, rites act as a protective factor or device for the conservation of sacred plants. So, it is the duty of the present generation to preserve and promote these aesthetic treasures to conserve biodiversity and nature, which will surely play a part in the progression of human beings. These sacred trees preserved through millennia by our ancestors as potential bio resources should be respected and conserved for the future generation. The sthalavrikshas is a mean of conservation of biodiversity.

\section{References}

1. Sudhakar (2016) Traditional knowledge of the Ancient Tamils conservation of sacred elements. International Education \& Research Journal 2(9).

2. Gunasekaran M, Balasubramanian P (2005) Sthalavriksha worship. A tool in plant conservation in Tamil Nadu, India pp. 163-166.

3. Amirthalingam M (1998) Sacred Trees of Tamil Nadu; A survey. CPR Environmental Education Centre, Chennai, India pp. 1-316.

4. Prabakaran R, Sabari Lakshmi (2017) Studies on Sthalavrikshas of various temples in Tamil Nadu, India. Bioscience Discovery 8(1): 6472.

5. Sukumaran S, Jeeva S, Prasad M (2010) Sacred forests of South Travancore of South India. Biological Diversity and Conservation 3(3): 10-14.

6. Gunasekaran M, Balasubramanian P (2012) Ethnomedicinal uses of Sthalavrikshas in Tamil Nadu, Southern India. Ethnobotany research and applications 1(8): 471-478.

7. Nandkishor S Zade (2013) Some Sacred Trees and their Medicinal Uses from Amravati District (Maharashtra). International Journal of Science and Research 4(1): 2729-2730.

8. (2013) IUCN. IUCN Red list of Threatened species, Version 2013 (1).

9. Matthew KM (1991) An Excursion Flora of Central Tamil Nadu, India Oxford and IBH Publications Co. Pvt. Ltd., Bombay, India.

10. Tholkappiyavathi K and Nadanakunjidam S (2013) A survey on sthalavriksha in the temple of nagapattinam environ. Journal of Science 3(2): 56-58.

\section{Your next submission with Juniper Publishers will reach you the below assets}

- Quality Editorial service

- Swift Peer Review

- Reprints availability

- E-prints Service

- Manuscript Podcast for convenient understanding

- Global attainment for your research

- Manuscript accessibility in different formats

( Pdf, E-pub, Full Text, Audio)

- Unceasing customer service

Track the below URL for one-step submission https://juniperpublishers.com/online-submission.php 